\title{
AN ANALYSIS INTO EARLY CUSTOMER EXPERIENCES OF SELF-SERVICE CHECKOUTS: LESSONS FOR IMPROVED USABILITY
}

\begin{abstract}
A B S TR A C T
The research aims to examine the perceptions of relative novice users of self-service checkouts (SSCOs) and if these perceptions change before, during and following use. Employing a diary approach with 31 respondents relatively unfamiliar with SSCOs, the research will document their experiences with this technology across stationary, hardware and grocery stores in two Scottish cities (Glasgow and Dundee). Findings suggest that the majority of respondents were motivated to use the technology because of time saving and convenience. However, the actual experience of using SSCOs was not always considered quicker when compared to staffed checkouts because of technical issues, lack of staff assistance and the impersonal, sometimes stressful and controlled nature of the cramped SSCO environment. Following post-use reflections, the majority of respondents' opinions did not change from their initial perceptions and indicated that they would prefer not to use the technology in the future. Based on the findings, this study makes some practical suggestions centring on the design and usability of SSCOs, which may go some way to reducing customer dissatisfaction and frustration with the technology, especially from the perspective of new users of the technology.
\end{abstract}

KEY WORDS

self-service checkouts, retail, control, customer experience

DOI: $10.2478 / \mathrm{emj}-2019-0003$
Corresponding author:

Jason J Turner

Taylor's Business School, Malaysia e-mail: JasonJames.Turner@taylors.edu.my

Andrea Szymkowiak

Abertay University, United Kingdom e-mail: a.szymkowiak@abertay.ac.uk

\section{INTRODUCTION}

The use of self-service technologies (SSTs) has been increasingly incorporated into the retail environment (Arnfield, 2014; Yang, Liu \& Ding, 2012; Jamal, 2004; Burke, 2002; Merrilees \& Miller, 2001) in recent years, with "many leading European retailers... heavily investing in self-scanning technology as part of their growth strategy" (Retail Technology, 2010, p. 1). SSTs are defined as technological interfaces, which assist the customer in the service process without the direct engagement of staff (Oyedele \& Simpson, 2007; Meuter et al., 2000) and are considered mutually beneficial to the customer and the retailer. Concerning customers, SSTs provide convenience, autonomy, and may save time spent queuing (Collier \& Kimes, 2013; Turner \& Borch, 
2012; Lee et al., 2010; Dabholkar, Bobbitt \& Lee, 2003; Meuter et al., 2000). For retailers, the technologies contribute to reducing labour costs and improving productivity (Kleemann, Voß \& Rieder, 2008; Anitsal \& Schumann, 2007). The use of these technologies changes the nature of the consumer-staff relationship to a consumer-technology relationship (Hilton et al., 2013), which, although creating a more autonomous experience, encourages a working consumer as a consequence (Anitsal \& Schumann, 2007; Voss \& Rieder, 2005).

It is within the context of an increased use of SSTs in general, and the SSCOs in particular, that this research will investigate its debated use and usefulness to consumers and retailers alike through an examination of consumer perceptions and experiences across multi-channel retailers. We focus specifically on the novice user and their perceptions prior, during and following interactions with selfservice technology; focusing on these users allows us to derive insights into the perceptions of the technology without these perspectives being influenced by past usage experience, both positive and negative. Given that SSTs have found acceptance with customers in the UK, following more than 15 years of increased implementation in retail, it will be informative to assess to which extent relatively novice users perceive its use, especially in terms of its perceived usability for new markets. The user group consisted of German individuals, who used an SST while being on an academic scholarship visit to the UK. According to the German EHI Retail Institute (2017), the number of self-service tills in German retail in 2017 was 3,200, which is low compared to the British retail figure, which was already over 15,000 by the end of 2011 (Retail Banking Research, 2011).
Given that SSTs are not as prevalent in German retail channels as it is in the $\mathrm{UK}$, the perceptions of this user group provided a unique opportunity to gauge user perceptions on already implemented (and user accepted) technology. Addressing an identified gap in the literature around the perspectives of novice users towards SSCOs, this research will inform solutions to consider in the design and usability of the technology for users to appeal to future markets of SSTs. The structure of the paper follows an established format, with an evaluation of the literature following this introductory section, where the evaluation will focus on customer interaction with SSCOs, perceived control and emotion. The methodology is then discussed, focusing on the justification for the approach, followed by results and discussion. The research concludes with a brief overview, underlining the significance of the study and makes recommendations for further research.

\section{LITERATURE REVIEW}

In recent years, a wide range of studies has investigated various aspects of the use of SSTs (Tab. 1). These research themes include the motivations for their use, the potential barriers to the successful integration of SSTs into a retail setting and the issue of theft and how SSCOs could encourage criminal activity. Research has also been conducted on the impact of a user's skill and experience levels, customers' preference for contact with personnel in relation to SSTs and the need for human-human interaction. The increased integration of SSTs into the retail environment has arguably created a distance between the customer and retailer (Wynne, 2016),

Tab. 1. Themes emerging from the literature on self-service technologies (SSTs)

\begin{tabular}{|l|l|}
\hline \multicolumn{1}{|c|}{ RESEARCH THEME } & \multicolumn{1}{c|}{ ACADEMIC RESEARCH } \\
\hline The motivation for the use of SSTs & $\begin{array}{l}\text { Anon, 2016; Anon, 2014; Lee et al., 2010; Dabholkar, Bobbitt } \\
\text { \& Lee, 2003; Meuter et al., 2000 }\end{array}$ \\
\hline Potential barriers to the integration of SSTs including theft & $\begin{array}{l}\text { A kesson, Edvardsson \& Tronvoll, 2014; Knapton, 2016; } \\
\text { Wynne, 2016 }\end{array}$ \\
\hline User skills and experience levels & Jayasimha \& Nargundkar, 2006 \\
\hline Consumer preference for human interaction & $\begin{array}{l}\text { Wang, Harris \& Patterson, 2013; Reinders, Dabholkar } \\
\text { \& Frambach, 2008; Collier \& Kimes, 2013; Simon \& Usunier, } \\
\text { 2007 }\end{array}$ \\
\hline Control of the consumer & $\begin{array}{l}\text { Lee \& Lyu, 2016; Reinders, Dabholkar \& Frambach, 2008; } \\
\text { Oyedele \& Simpson, 2007; Nysveen, Pederson } \\
\text { \& Thorbjornsen, 2005; Hoffman, Novak \& Schlosser, 2003; } \\
\text { Venkatesh, 2000 }\end{array}$ \\
\hline
\end{tabular}


and raised issues in the literature around consumer control. The research, however, in each of these areas is not exhaustive, with only a few studies specifically examining customer interactions with an SST and SSCOs (Steenkamp \& Maydeu-Olivares, 2015; Lee et al., 2010; Dean, 2008; Dabholkar, Bobbitt \& Lee, 2003; Meuter et al., 2000), which suggests further work could be done in this area.

The Technology Acceptance Model (TAM) (Davis, 1989) is one of the most widely recognised frameworks to model user intentions towards the use of technology. It has informed the more recent model of Unified Theory of Acceptance and Use of Technology (UTAUT) (for a comprehensive overview see Venkatesh, Thong \& Xu, 2016). TAM's core components (Davis, 1989) suggest that perceived usefulness and perceived ease of use directly impact on the intention to use a technology (Davis \& Wiedenbeck, 2001), which in turn determines usage behaviour of this technology; furthermore, social and cognitive instrumental processes also mediate user acceptance (Venkatesh \& Davis, 2000). Interestingly, increased experience with a system induced individuals to continue to judge a system's usefulness based on potential status benefits resulting from its use, and to rely less on social information in forming perceived usefulness and intention, pointing to a differentiated effect of social influence depending on system usage. Ease of use is also of importance for developing trust relationships with technology, and more so than general and organisational trust of users (Ejdys, 2018; Ejdys \& Halicka, 2018).

\subsection{CONSUmer Satisfaction With SSCOS}

The use of an SSCO is not confined to one retail sector, although they have proved popular among those retailers where saving time and convenience are important factors to the customer experience. Typically, consumers using self-service benefit from less queuing time, and can expedite their transaction in a quick, convenient and autonomous manner (Jones, 2016; Jammi, 2014; Collier \& Kimes, 2013; Lee et al., 2010; Muller, 2008).

However, are customers satisfied with their experience of SSCOs? According to Engel et al., (1995, p. 481) customer satisfaction is associated with "the outcomes of the subjective evaluation that the chosen alternative (the store) meets or exceeds expectations." If a customer is satisfied with the 'usability' experience and/or has the perception that their expectation has been exceeded, then the customer's willingness to increase the frequency of their visits to the store and as a result their purchases (McNamara \& Kirakowski, 2008; Venetis \& Ghauri, 2000; De Ruyter \& Bloemer, 1999) should also increase. The reverse is also true: dissatisfied customers are likely to decrease the frequency of visits and spending in the store. The question of the role SSCOs play in a consumer's satisfaction and repeat patronage of a store (Hogarth et al., 2004; Bloemer and De Ruyter, 1998; Mittal and Lassar, 1998) is not, however, easily answered, as there are several variables associated with consumer satisfaction (Tab. 2). These variables include, and are by no means an exhaustive list, the product range, consumer service, the specific role of the employee, price and promotion, store atmospherics and location.

Customer judgement of satisfaction is argued to centre on the quality of their experience with the product and/or service (Beerli et al., 2004; Andreassen \& Lindestad, 1998; Liu, Yang \& Liu, 2017; Oliver, 1997; Oliver, 1993) and the perceived value they receive (Andreassen \& Lindestad, 1998). The gap

Tab. 2. Themes emerging from the literature on customer satisfaction

\begin{tabular}{|l|l|}
\hline \multicolumn{1}{|c|}{ RESEARCH THEME } & \multicolumn{1}{c|}{ ACADEMIC RESEARCH } \\
\hline Product range & Yavas \& Babakus, 2009; Miranda, Konya \& Havrila, 2005 \\
\hline Customer service & $\begin{array}{l}\text { Butcher et al., 2001; Heskett et al., 1997; Javalgi \& Moberg, } \\
1997\end{array}$ \\
\hline The role of the employee & $\begin{array}{l}\text { Collier \& Kimes, 2013; Lee et al., 2010; Wong, 2004; Swan, } \\
\text { Bowers \& Richardson, 1999 }\end{array}$ \\
\hline Price and promotion & $\begin{array}{l}\text { Miranda, Konya \& Havrila, 2005; Uusitalo, 2001; Urbany, } \\
\text { Dickson \& Sawyer, 2000 }\end{array}$ \\
\hline Store atmospherics and location & Yavas \& Babakus, 2009; Miranda, Konya \& Havrila, 2005 \\
\hline
\end{tabular}


between what was expected, what was delivered, and the interplay between the expected, experienced and perceived function (Andreassen \& Lindestad, 1998; Grossman, 1998; Anderson et al., 1994) can be argued to be an important determinant when examining customer engagement with SSCOs.

\subsection{CONSUMER DISSATISFACTION WITH SSCOs}

Vouk, Guszak and Sisek (2011), Meuter et al., (2000) found that customers were generally dissatisfied with the technology, specifically the handling of price discrepancies, the purchasing of alcohol, barcodes which were not easily scanned and a customer's ability to collect 'change' or returned money (Dillon, 2010). These factors, which influence levels of satisfaction and dissatisfaction taken in the context of whether users of SSCOs see themselves as co-creators (Hilton et al., 2013; Ballantyne, Williams \& Aitken, 2011) or working customers (Anitsal \& Schumann, 2007; Voss \& Rieder, 2005), impact on customer perceptions and the emotional investment with the interaction. It is this issue of dissatisfaction and its relationship with the user's emotional state, in particular the issues of control (Lee \& Lyu, 2016; Oyedele \& Simpson, 2007; Nysveen, Pederson \& Thorbjornsen, 2005; Wong, 2004) and frustration (Bessière et al., 2006; Lazar et al., 2006), which will be investigated further in this research.

\subsection{Perceived Control}

A consumer's use of an SSCO can also be argued to be founded on the need to be in control (Lee \& Lyu, 2016; Oyedele \& Simpson, 2007; Hoffman, Novak \& Schlosser, 2003), which "enhances consumer evaluations of this process and also directly impacts intentions to use the option" (Dabholkar, 1996, p. 36). However, when these feelings of control are disrupted by, say, staff intervention (Hilton et al., 2013; Dabholkar \& Bagozzi, 2002), consumer frustration may emerge. The emotional state of frustration occurs when an individual has their route to goal achievement blocked (Bessière et al., 2006). Relating control and emotion to an individual's use of SSCOs, the goal achievement would be a quick, convenient and autonomous transaction (Lee et al., 2010; Dabholkar, Bobbitt \& Lee, 2003; Fitzsimmons, 2003; Meuter et al., 2000). The blocks to this achievement would be internal (e.g., lack of knowledge and/or ability) and/ or external (e.g., the physical environment and/or other individuals, for example, staff required to assist in the transaction process) (Bessière et al., 2006). If a consumer feels frustrated, requiring assistance and/ or approval to continue the process (Jones, 2015) rather than being in control of the process, future customer intentions may be to avoid using the technology altogether (Bessière et al., 2006; Lazar et al., 2006). It has been shown that self-efficacy (Bessière et al., 2006), i.e., the belief in one's own capability to achieve a goal or outcome (Locke \& Latham, 1990), influences levels of frustration and, in turn, the commitment to the interaction (Bandura, 1986). In the case of SSCOs, if a customer is unable to achieve his/her goal with the used technology, customers may become more frustrated and dissatisfied with SSCOs and be less committed to using the technology (and perhaps the retailers who have them), consistent with a lack of perceived usefulness and ease of use of the technology (TAM).

\section{MeTHODOLOGY}

\subsection{Current Study}

The current study addressed two research questions: 1) what are the perceptions of relative novice users of SSCOs and 2) do these perceptions change before, during and following the use? Both questions were explored prior to a larger empirical study comparing familiar and unfamiliar users of SSCOs (not reported here). Because of their lack of familiarity with SSTs in general and SSCOs in particular, it was anticipated that the research group used in this study, i.e., unfamiliar with the use of SSCOs, would be able to provide a detailed account of their customer journey through unbiased eyes, a perspective that would be less likely from an experienced user due to their prior knowledge and pre-conceptions. Given that SSTs have been around for several years in the UK, with the refinement of the technology and, thus, improvement of usability aspects, it was a unique opportunity to assess how users relatively unfamiliar with the technology were interacting with it. It is acknowledged that this approach could be considered to have the limitation related to the focus on a specific cohort of consumers, thus affecting generalisability. However, the research intended to examine this particular cohort of consumers given their ability to provide a unique perspective, so it was not deemed a limitation. In addition, while the sample size was arguably small, the richness of data generated from this diary 
approach painted a comprehensive picture of the consumer experience. From a practical point of view, the findings would be of relevance for companies exploring the use of SST in future markets. The theoretical contribution of the work surrounds the exploration of whether perceptions of SSTs change with their usage. Depending on the nature of the respondent's experience, the findings reveal the extent to which user perceptions compare with the other findings that suggest usefulness perceptions may be affected by experience with a technological system (Venkatesh \& Davis, 2000). Addressing these questions will consolidate the existing literature and take research forward in the area of user perceptions and usage of SSTs.

This research used a qualitative diary method approach with 31 German respondents (23 females and eight males, aged between 20 and 42, with a median age of 20.5) who had limited experience with SSCOs and were visiting Scotland as part of their academic studies.

The majority of respondents reported having had very occasionally or never used SSCOs in their home country; those few who had used SSTs did so in electronic stores, grocery stores, petrol stations and furniture/hardware stores. A lack of engagement with SSCOs did not, however, mean that respondents did not understand what SSCOs were; all respondents were able to define the technology using key phrases such as "scanning and purchasing products by yourself" and "without the support of staff." A typical response was "self-scan checkouts (SSCOs) means that the whole purchasing process will be done without the help of a staff member." Respondents' understanding of the concept provided evidence that SSCOs were not an alien concept to the cohort and that they knew of their existence and function although they were less or not familiar with the use of the technology. The responses also underlined the understandable nature of the diary questions, which were also piloted to ensure clarity of their phrasing.

The respondents were asked to document their experiences with SSCOs across multichannel retailers, which included a stationery retailer, a grocery retailer and a hardware retailer operating in Glasgow and Dundee. The diary approach allowed the capture of customer perceptions and experiences of SSCOs prior to the use, during the use and following the use in real time (Laurenceau \& Bolger, 2005), "in their natural, spontaneous context" (Bolger, Davis \& Rafaeli, 2003, p. 580), thus reducing the limitations of retrospection (Bolger, Davis \& Rafaeli, 2003). An often-cited limitation of this approach was the burden put on the participant, however, in line with good practice (Bolger, Davis \& Rafaeli, 2003); the diary was designed to be short and took only several minutes to complete at each stage of the customer journey using SSCOs at various retail locations. The responses were analysed using content analysis so that the research could gain a broad description of the respondent experiences and, subsequently, some understanding of identified phenomena (Elo \& Kyngäs, 2008; Pirzada, 2016). This approach allowed for the interpreting of meaning and relationships (Denzin \& Lincoln, 2011) within and between the stages of SSCO engagement. Coding was vital in assigning meaning to the statements, with open coding used to unlock the data and their importance for existing theory (Strauss \& Corbin, 2008).

\section{RESULTS AND DISCUSSION}

To address the aims of this research, the qualitative responses were grouped around three main themes: respondent perceptions of SSCOs prior to the use; respondent experiences during the use; and, after having used the technology, respondent post-use reflections including perceptions of the future use and suggestions on how to improve the design, usability and experience of SSCOs. Throughout the analysis, representative quotes from respondents were used to illustrate themes that emerged from the diary reporting.

\subsection{CUSTOMER PERCEPTIONS PRIOR TO USING SSCOS (IN-STORE EXPERIENCE)}

The majority of respondents thought the usage of SSCOs in general, but particularly for grocery retail, would have a negative effect on the in-store experience of customers, specifically the organisation's ability to build relationships with customers, leaving them, in some cases, feeling isolated (Tab. 3). A minority of respondents added that this feeling could be particularly acute among older customers, which they expected to feel confused and isolated if they used SSCOs due to the potential effects of the digital divide, an emotional theme that is consistently revealed in this research and will be revisited later in the discussion.

A minority (four) of respondents thought that SSCOs could have a positive impact on the shopping experience of families, allowing children to be more 
Tab. 3. Respondent perceptions prior to using SSCOs (in-store experience)

\begin{tabular}{|l|l|}
\hline \multicolumn{1}{|c|}{ THEME } & \multicolumn{1}{c|}{ REPRESENTATIVE QUOTE } \\
\hline $\begin{array}{l}\text { Negative impact - the lack of } \\
\text { relationship-building leading to isolated } \\
\text { users }\end{array}$ & $\begin{array}{l}\text { "the company isn't able to interact with the people, there's no possibility to build } \\
\text { up any social contacts or personal loyalty to the customer" } \\
\text { organisation, this might lead to negative experiences for the customer if he feels } \\
\text { alone in the customer journey" }\end{array}$ \\
\hline $\begin{array}{l}\text { Positive impact - allow child } \\
\text { engagement in the shopping process }\end{array}$ & "for children it's an attraction, to be more involved in shopping" \\
\hline $\begin{array}{l}\text { Positive impact - financial savings for } \\
\text { the organisation }\end{array}$ & $\begin{array}{l}\text { "the benefits are for the organisation, it creates unemployment replacing workers, } \\
\text { mostly mothers working part-time, with machines" }\end{array}$ \\
\hline $\begin{array}{l}\text { Positive impact - trusting the user } \\
\text { "[it] makes the customer feel like they are processing shopping quicker, have extra }\end{array}$ \\
\hline
\end{tabular}

involved in the shopping process. In their opinion, the use of the technology was easier if more than one person was involved and that the technology appealed to younger people. This observation was supported by Dean (2008). An interesting addition to comments relating to the involvement of children was that SSCOs could have a particularly beneficial impact on parents with smaller children, as it was noted by some respondents that SSCOs "have no sweeties" next to the check-out area.

A minority (four) of respondents referred to the financial savings for the organisations as a benefit of SSCOs. This particular finding is consistent with the notion that SSCOs create the working customer (Anitsal \& Schumann, 2007; Voss \& Rieder, 2005), replacing the customer-employee relationship with a customer-technology one (Hilton et al., 2013) which reduces organisational labour costs (Kleemann, Voß, \& Rieder, 2008; Anitsal \& Schumann, 2007).

One respondent stated that SSCOs gave customers the impression that the organisation trusted them to complete the purchasing transaction themselves, providing them with a choice to use staffed or non-staffed checkouts and overall quicker experience in a more modern retail environment. This was a particularly interesting observation, and the respondent thought that rather than creating a working customer (Anitsal \& Schumann, 2007; Voss \& Rieder, 2005), the organisations were, in fact, empowering customers, trusting them to complete their transaction without the need for staff. However, as we will observe later in the research, respondents noted that staff were very much required to complete many of the transactions.

Another respondent argued that SSCOs would not play either a positive or negative role in the customer experience of an organisation, with customers simply accepting the technology as part of the retail experience. This respondent argued that SSCOs simply provided an alternative to customers for when it was needed, for example, when a customer had a limited amount of time in which to shop, when the customer was presented with long queues at staffed checkouts and/or when the customer had a small number of products to purchase, findings which are supported by the literature (Turner \& Borch, 2012; Lee et al., 2010; Dabholkar, Bobbitt \& Lee, 2003; Meuter et al., 2000).

\subsection{CUSTOMER PERCEPTIONS PRIOR TO USING SSCOS (MOTIVATION)}

The respondents were asked to document their motivations for using SSCOs based on their in-store observations but before engaging with the technology. The analysis of the respondents' diaries revealed two predominant themes, namely, 1) time saving because of shorter queues and 2) convenience when the customer had a small number of low involvement items. These themes are consistent with the findings by other researchers (Turner \& Borch, 2012; Lee et al., 2010; Dabholkar, Bobbitt \& Lee, 2003; Fitzsimmons, 2003) and, as observed earlier, they provide some insight into why customers would use the technology as an alternative to staffed checkouts to be used when customers deemed it appropriate.

Respondents were asked to document situations in which they would and would not feel like using SSCOs. It should be re-emphasised that respondents had been familiar with the concept of self-service but had not used the technology regularly. The comments clearly indicated that respondents could imagine scenarios for usage of SSCO, which were based on potential exposure to it.

The majority of respondents indicated that certain criteria were necessary for using or not using the technology (Tab. 4). The criteria included a low 
Tab. 4. Circumstances under which respondents feel they would use or not use SSCOs

\begin{tabular}{|c|c|}
\hline THEME & REPRESENTATIVE QUOTE \\
\hline Having a low number of products & $\begin{array}{l}\text { "I wouldn't buy a lot of products or high involvement products at self-service } \\
\text { because I want to get some advice for the product and want to get everything } \\
\text { checked" }\end{array}$ \\
\hline Small-sized products, light in weight & $\begin{array}{l}\text { "it's just easier and quicker to pack a few products which are light and easy to } \\
\text { handle" }\end{array}$ \\
\hline Low complexity products & $\begin{array}{l}\text { "I prefer to use staffed checkouts if I have fruit or something, products without } \\
\text { barcodes because I don't know how to handle them" }\end{array}$ \\
\hline Long queues at staffed checkouts & "I wouldn't use self-service if there is a staffed check out without a very big queue" \\
\hline $\begin{array}{l}\text { Convenience products purchased every } \\
\text { day }\end{array}$ & "convenience products, low involvement, which I've had experience with" \\
\hline $\begin{array}{l}\text { Sufficient space surrounding the } \\
\text { checkout area }\end{array}$ & $\begin{array}{l}\text { "there isn't space at self-service checkouts [SSCOs], you are close to other } \\
\text { customers and if the barcodes don't scan or you don't know where the barcodes } \\
\text { are you are taking a lot of time" }\end{array}$ \\
\hline The emotional state of the consumer & $\begin{array}{l}\text { "I would use self-service if I'm sad and I don't want to speak to anyone" } \\
\text { "If I felt lazy or tired I would use self-scan" }\end{array}$ \\
\hline
\end{tabular}

number of products; products small in size and light in weight; complex products, i.e. where the barcodes were not clearly displayed; long queues at staffed checkouts; convenience products which were familiar and of low involvement (i.e. products which did not require much thought, those purchased almost every day); limited space around the checkout area and, interestingly, the emotional state of the purchaser.

The reasons respondents provided for use and non-use of SSCOs centred on the nature of the product(s) and appeared reasonable from an operational point of view. It makes sense that having a large number of items would encourage respondents to use a staffed checkout given the anticipated level of assistance required and space available. It is also conceivable that respondents would not choose to use an SSCO for products which were not convenience products, or require high "involvement", as they might require a staff member to assist or perhaps remove the security tag from some products, an issue identified in the literature (Vouk, Guszak \& Sisek, 2011; Dillon, 2010; Meuter et al., 2000). It was interesting, however, that respondents cited complexity of a product as a reason for not using SSCOs; by complex the respondents meant products without a visible barcode. The last two themes could perhaps have been grouped into one theme, relating to specific product features; however, they were kept separate as the aspect of familiarity distinguished between the two, with complex products still being familiar products, i.e. purchased regularly.

Another interesting observation was the fact that some respondents would not use SSCOs for large and difficult to handle products; arguably, the same level of effort is required to lift a bulky item onto the conveyor belt of a staffed checkout, as it is to put it through a SSCO. Therefore, the interpretation from the respondents' diaries is that the respondents thought larger, bulkier items were perhaps more difficult to scan, i.e. finding the barcode and positioning the product to enable it to be scanned. The interpretation is also supported by the literature, with the scanning of barcodes identified as a potential barrier and a cause of consumer dissatisfaction and frustration (Vouk, Guszak \& Sisek, 2011; Dillon 2010; Meuter et al., 2000). Not being able to find barcodes could lead to a customer waiting for assistance at SSCOs, which would make some respondents feel "controlled", an emotional state, which, in their words, turned to stress, but not aggression, which was identified in the literature (Knapton, 2016).

We can further observe from the diaries that many respondents thought that SSCOs were impersonal, encouraging antisocial behaviour due to the limited interaction with people. Respondents thought the area created an environment where people of mixed experience and skills with the technology stood close to each other leading to a state of irritation and stress, heightened by situations where the transaction was not smooth. As one respondent put it, "it makes shopping very unpersonal [sic] and unsocial because you could do your purchases without talking, watching or interacting with somebody" and "the space is limited, you feel rushed, there is usually a queue, and people push past you making you stressed".

Many respondents thought the SSCO environment encouraged 'crowding' (Dabholkar \& Bagozzi, 2002), and had the drawback of creating negative emotions due to space stress, compounded 
by failures in the process and the lack of staff relationships. It seems reasonable to suggest that staff training, i.e. when to be present but not a threat or stressor at SSCOs, seems to be a critical issue. Consumers appear to value the social interaction with others as part of the service encounter, which is consistent with the literature (Jammi, 2014; Simon \& Usunier, 2007) and informs the discussion of perspectives towards SSCOs prior to their use.

\subsection{RESPONDENT PERCEPTIONS OF SSCOS DURING THEIR USE}

Following the logging of respondent perceptions, motivations and evaluation of the role of SSCOs on the retail experience, they were prompted to document their actual use of the technology. Respondents were asked to document their transactional journey with SSCOs, outlining the process from start to finish which included, although not exclusively, the following stages: approaching the SSCO, scanning products, placing products into bags, making a payment, receiving the receipt and change/ money back and exiting the SSCO area. Throughout this process, respondents were asked to identify issues with the current process and how these were resolved.

Unsurprisingly, the majority of respondents followed on-screen instructions at the SSCO and found the process relatively easy to follow. A typical walk-through from respondents was the following: placed the products on the left- or right-hand side of the SSCO, scanned products, placed products in bags provided on the right- or left- hand side of the checkout, chose the method of payment, made the payment, collected the receipt, change and bags and exited the checkout area. One respondent placed the products on the wrong side (the bagging side) of the SSCO and could not understand why they were unable to proceed with their transaction. However, following some prompting from a friend accompanying the respondent, they placed the products on the correct side of the checkout. This particular respondent also documented that they had difficulties scanning fruit, which required further assistance from the same friend; they stated, "fruit had no barcodes, so I don't know how to handle them". In both cases, the respondent acknowledged that they had not followed the on-screen instructions.

In terms of respondent experiences with SSCOs, identifying any problems around the design and usability, which affected their dissatisfaction and frustration, the research revealed that all but one of the respondents encountered problems, which were either technical or process-related (Tab. 5). The majority identified technical problems, followed by process problems, predominantly around the purchasing of alcohol or by simply being unable to proceed with the scanning of products. Typically, in these instances, respondents received a message indicating the need for a member of staff to intervene and enter a code to allow the respondent to proceed with their transaction. The specific scanning problems identified by respondents were: scanning products with no barcode; scanning products on special offer or reduced price; having some products that were expected to have a barcode but did not have one and vice versa. These issues were compounded by the necessity to have a staff member's assistance and the time taken for issues to be resolved typically because "there was (usually) only one member of staff and she was solving other issues."

A minority of respondents identified problems with the process of the SSCO transaction, centring around three key issues. The first issue surrounded the placing of products prior to and following scanning on either side of the scanner. Those respondents argued that placing the products, particularly in the bagging area of the checkout frequently led to a verbal message "unexpected item in the bagging area" which required a staff member's assistance to allow the process to continue. The second issue - the lack of space on either side of the SSCO and between checkouts - raised by respondents was directly related to the first and raised throughout this research. Respondents felt that there was a limited amount of space to place the basket, which also interfered with individuals at the adjacent checkout who were putting products into bags in the bagging area. The third and final issue raised by respondents was related to the payment stage of the transaction process. Some respondents indicated that making payments with Scottish banknotes posed a problem, with the SSCOs repeatedly refusing to accept the note.

These observations made by participants are consistent with those made by other researchers, namely, the possibility that SSCOs could actually prolong the transaction instead of enabling a fast and convenient service, which SSCOs are supposed to deliver (Turner \& Borch, 2012; Dabholkar, Bobbitt \& Lee, 2003; Dabholkar \& Bagozzi, 2002; Meuter et al., 2000). Issues surrounding barcodes and agerestricted purchases, such as alcohol, which require the intervention of a staff member, impact negatively 
Tab. 5. Themes that emerged from the use of SSCOs

\begin{tabular}{|c|c|}
\hline THEME & REPRESENTATIVE QUOTE \\
\hline Technical problems (Barcodes) & $\begin{array}{l}\text { "I struggled with a baguette from the bakery section. I thought I had to manually } \\
\text { put the item in but it, in fact, had a barcode printed on it which I found confusing } \\
\text { as which bakery items should be scanned and which should be put in manually" }\end{array}$ \\
\hline $\begin{array}{l}\text { Technical problems (staff member } \\
\text { intervention) }\end{array}$ & $\begin{array}{l}\text { "It was frustrating to realise that if you buy alcohol at the self-scan you have to wait } \\
\text { for a staff member. He has to check your ID to check how old you are. After the } \\
\text { check of the staff member you can go on" and "the scanner didn't realise that the } \\
\text { scanned items were placed on the desk, so the interaction always stopped, and } \\
\text { a staff member was needed" }\end{array}$ \\
\hline $\begin{array}{l}\text { Processual problems (placement of } \\
\text { products) }\end{array}$ & $\begin{array}{l}\text { "I usually kept all my items in my hands [not placing them in the bagging area] and } \\
\text { was wondering why I couldn't continue" and "when I was scanning my products I } \\
\text { laid my umbrella down in the bagging area and wasn't able to continue until } \\
\text { a member of staff came and typed in a code" }\end{array}$ \\
\hline $\begin{array}{l}\text { Processual problems (lack of space at } \\
\text { the checkout) }\end{array}$ & $\begin{array}{l}\text { "I wanted to scan many products but there is too little space for all the products, } \\
\text { so I decided to go to the staffed checkout" }\end{array}$ \\
\hline Processual problems (payment) & $\begin{array}{l}\text { "the machine wouldn't accept the Scottish notes; I kept trying until someone came } \\
\text { to help" }\end{array}$ \\
\hline
\end{tabular}

upon the nature of the transaction (Anon, 2014; Oyedele \& Simpson, 2007; Dabholkar, Bobbitt \& Lee, 2003; Fitzsimmons, 2003; Dabholkar \& Bagozzi, 2002; Meuter et al., 2000). The role of the staff is an important theme. Firstly, it is important to note the assistance they provide in case of a problem, i.e. entering a code to allow the user to proceed with the transaction, which ultimately gives the control over the transaction to the member of staff rather than the consumer. Secondly, the limited number of staff members at the bank of SSCOs delays the response time to transactional problems. These identified issues have the potential to give rise to negative feelings and emotions, such frustration, stress, the sense of isolation and/or being controlled (Anon, 2016; Oyedele \& Simpson, 2007; Bessière et al., 2006, Lazar et al., 2006; Nysveen, Pederson \& Thorbjornsen, 2005; Hoffman, Novak \& Schlosser, 2003; Venkatesh, 2000) and could impact on user perceptions and the future use of SSCOs.

The findings point to the use of several measures commensurate to the identified issues. These could include, among others, staff training to ensure positive interactions with customers, more staff to assist customers, a more generous layout of SSCOs and surrounding spaces to avoid problems arising from placing products in the wrong area in and around the SSCOs. These suggestions, however, may not be consistent with store policies, where resources may be limited and, therefore, an appropriate balance between necessary, desirable and feasible changes has to be found. Such suggestions are discussed later in the research and considered as part of further research.

\subsection{RESOLVING IDENTIFIED ISSUES}

When the research investigated how respondents resolved the identified technical and processual issues, opinions were evenly divided between the respondents resolving the issue themselves and having a staff member resolve the issue on their behalf (Tab. 6). Those respondents who dealt with the issue themselves did so by either waiting or persevering until the problem was resolved. The situations where those respondents resolved the issue themselves involved making the payment and/or attempting to process barcodes; a typical response was "I kept trying as there was a lack of assistance and, eventually, I got there." With regard to those respondents who waited for a member staff to assist, they also had issues making the payment and/or attempting to process barcodes. The majority of respondents who had a staff member provide assistance in the transaction would have preferred to resolve the issue themselves and remained in control, an issue consistent with that found by others (Oyedele \& Simpson, 2007; Nysveen, Pederson \& Thorbjornsen, 2005; Hoffman, Novak \& Schlosser, 2003) and which also links to a theme emerging from this research regarding respondents feeling controlled either positively or negatively by the technology. However, those respondents felt they had no choice but to receive staff assistance, as they were unable to continue without the intervention from a member of staff (indicated by a red light above the SSCO). The extent, to which these negative experiences influenced overall respondent reflections of their use, and the 
Tab. 6. Themes that emerged during the use of SSCOs (resolving problems)

\begin{tabular}{|l|l|}
\hline \multicolumn{1}{|c|}{ THEME } & \multicolumn{1}{c|}{ REPRESENTATIVE QUOTE } \\
\hline Resolved by the user (waited) & "for the problem to resolve itself" \\
\hline Resolved by the user (persevered) & "I just kept trying until it eventually worked" \\
\hline $\begin{array}{l}\text { Resolved by a member of staff (no } \\
\text { choice) }\end{array}$ & $\begin{array}{l}\text { "without them [the staff member] it is difficult to complete the process" and “I } \\
\text { scanned an item and couldn't continue. A staff member erased the item but didn't } \\
\text { tell me what went wrong. I felt like it could happen again at any time" }\end{array}$ \\
\hline
\end{tabular}

Tab. 7. Themes in relation to a customers' emotional state following the use of SSCOs

\begin{tabular}{|l|l|}
\hline \multicolumn{1}{|c|}{ THEME } & \multicolumn{1}{c|}{ REPRESENTATIVE QUOTE } \\
\hline Stressed & $\begin{array}{l}\text { "using self-service makes me feel stressed. It's complicated and it's very annoying } \\
\text { to wait for services" }\end{array}$ \\
\hline Nervous & $\begin{array}{l}\text { "I felt stressed and nervous before using self-scan and a little bit lost and stressed } \\
\text { when I used it" }\end{array}$ \\
\hline Frustrated & $\begin{array}{l}\text { "I felt frustrated as the process was slow, frustrating and probably slower than } \\
\text { queuing at a staffed checkout" }\end{array}$ \\
\hline Controlled & "I felt controlled relying on staff and having staff always around" \\
\hline
\end{tabular}

future use of SSCOs will be described in subsequent sections.

\subsection{RESPONDENT PERCEPTIONS OF SSCOS FOLLOWING THE USE}

Respondents were asked to document how their experience using SSCOs made them feel, addressing the emotional dimension of the customer-technology experience (Hilton et al. 2013). This provided further insight into experienced frustration, control and, in some cases, stress as well as the positive and negative emotional motivators behind the use of SSCOs (Tab. 7). The majority of respondents felt stressed and nervous prior to the use and, to a degree, during the use of SSCOs. A minority of respondents felt frustrated as they thought the process would be easier and/or quicker than a staffed checkout. The issue of frustration has been revealed in previous research (Bessière et al., 2006; Lazar et al., 2006; Bandura, 1986) and is linked to the issue of control, which was also raised by a minority of respondents. Control is observed as a key emotion and motivator in using SSTs (Oyedele \& Simpson, 2007; Nysveen, Pederson \& Thorbjornsen, 2005; Hoffman, Novak \& Schlosser, 2003; Venkatesh, 2000). The majority of respondents felt controlled having to wait for assistance and/or service, and, to a degree, isolated by the process. These themes have been observed throughout this research and the literature (Oyedele \& Simpson, 2007; Nysveen, Pederson \& Thorbjornsen, 2005; Hoffman, Novak \& Schlosser, 2003; Venkatesh, 2000) and will be an area for future empirical research. In the interests of completeness, it should also be noted that a minority of respondents felt indifferent about the process, and indicated they felt "nothing." A further respondent stated that they felt excited by the process, as it was a new experience for them.

\subsection{FUTURE USE OF SSCOS BY RESPONDENTS}

The majority of respondents indicated that following the repeated use of SSCOs during their time in Scotland, their opinions had not changed, and those respondents felt the interaction with the technology was in line with their expectations. In the future, they would prefer not to use SSCOs again. Reasons for any future use are related to being in a hurry, long queues at staffed checkouts or in the case of one respondent, feeling sad (Tab. 8), which was again indicated by the same respondent when asked about possible circumstances for the use of SSCOs. Sadness as a reason for the use and the future use is an interesting finding and gives further insight into the rationale for the preference of the technology, which is related to the desire to be left alone, arguably wanting to be in control of the parameters of their personal engagement. Sadness as a feeling is related to emotion and the control debate when an individual does not wish to interact with anyone and may choose to use an SSCO. This, perhaps, eludes to one of the negative aspects of SSTs, the lack of human interaction, unless, of course, it is the sense of control perceived because of staff intervention.

A minority of respondents felt that their opinions had changed and that they now looked favourably 
Tab. 8. Themes that emerged in relation to the future use of SSCOs

\begin{tabular}{|l|l|}
\hline \multicolumn{1}{|c|}{ THEME } & \multicolumn{1}{|c|}{ REPRESENTATIVE QUOTE } \\
\hline $\begin{array}{l}\text { Has not changed - Would only use } \\
\text { again in the case of rushing or long } \\
\text { queues at staffed checkouts }\end{array}$ & $\begin{array}{l}\text { "my opinion hasn't changed. I would only use self-scan in the future if I'm in a hurry } \\
\text { and the queue is too long" }\end{array}$ \\
\hline $\begin{array}{l}\text { Has not changed - Would only use it } \\
\text { again if they were sad }\end{array}$ & "sad and I don't want to speak to anyone" \\
\hline $\begin{array}{l}\text { Has changed - SSCOs were not as } \\
\text { quick as they first thought }\end{array}$ & $\begin{array}{l}\text { "it's meant to be quicker but [having used SSCOs] I think it's slower than staffed } \\
\text { check-outs" }\end{array}$ \\
\hline $\begin{array}{l}\text { Has changed - SSCOs were less } \\
\text { complicated and quicker than first } \\
\text { thought }\end{array}$ & $\begin{array}{l}\text { "firstly, I thought it's too complicated, but usually it's quite simple and I like to } \\
\text { speed the purchase up" }\end{array}$ \\
\hline $\begin{array}{l}\text { Has changed - SSCOs allowed more } \\
\text { control }\end{array}$ & $\begin{array}{l}\text { "I like the self-service and will use it in the future. I find it very comfortable } \\
\text { and I like to have the option, handle the speed of scanning/buying on my own" }\end{array}$ \\
\hline
\end{tabular}

Tab. 9. Themes that emerged regarding recommendations for SSCOs

\begin{tabular}{|l|l|}
\hline \multicolumn{1}{|c|}{ THEME } & \multicolumn{1}{c|}{ REPRESENTATIVE QUOTE } \\
\hline $\begin{array}{l}\text { More staff to be employed in and } \\
\text { around the SSCO area }\end{array}$ & $\begin{array}{l}\text { "there should be more members of staff who can help the customer, so that the } \\
\text { progress stays quickly" }\end{array}$ \\
\hline The need for more space & $\begin{array}{l}\text { "it would be helpful to have an area where I can store my bag or umbrella so that } \\
\text { there are no unexpected items in the bagging area" }\end{array}$ \\
\hline Ensure SSCOs worked every time & $\begin{array}{l}\text { "if everything works, there will be no frustrations anymore, but if the machine } \\
\text { doesn't work without failures then the customer will be getting angrier and more } \\
\text { frustrated" }\end{array}$ \\
\hline
\end{tabular}

towards SSCOs and would use the technology again, citing being in control, able to scan at one's own pace as the main reason for future use. These findings reinforced the previous commentary given in the research and the commentary given in the literature, namely, that respondents used SSCOs for convenience and to save time (Turner \& Borch, 2012; Lee et al., 2010; Dabholkar, Bobbitt \& Lee, 2003; Fitzsimmons, 2003; Meuter et al., 2000). Of the minority of respondents whose opinions had changed following repeated use of SSCOs, many reiterated the claim that the technology was not as quick and convenient as they first thought it would be.

\subsection{RESPONDENT RECOMMENDATIONS REGARDING THE DESIGN AND USABILITY}

To address the issues concerning dissatisfaction and frustration with SSCOs respondents were asked to suggest improvements. There were three main themes to emerge from the responses (Tab. 9) and some one-off suggestions. The first theme to emerge and which is linked to a common theme to arise from the research overall, was that the majority of respondents indicated the need for more staff to be employed in and around the SSCO area. The second theme raised by several respondents was the need for more space (a minority suggested raising the tables on either side of the terminal) for allowing customers to pack their products into bags and store their personal items. The third theme raised by several respondents, as a means of reducing more customer frustrations was to ensure SSCOs worked every time. Some respondents added suggestions regarding the improvement of the infrastructure, such as weighing and the onscreen communication, employing more staff that were trained to use phrases such as "now it will work" and/or "okay, it is working now."

Other one-off comments provided by respondents included the need for barcodes on all sides of the product; a better scanner, which recognised more products, which links to the third theme that emerged from the responses. One respondent suggested having the dispensing of coins and cash closer together. Clearer instructions at eye level on the scanning process was mentioned by one respondent with a Q\&A poster, which outlines typical SSCO problems and suggested solutions mentioned, by another respondent. One respondent suggested a money-off coupon being dispensed if the customer encountered a problem with the SSCO as a means of addressing customer frustrations. Surprisingly, given the common theme to emerge from this research, only two respondents felt there was a need for more user autonomy, one indicated it would be useful to allow 
users to delete items wrongly entered without having to ask for assistance and another respondent requested a button to be installed in the checkout area to ring for help which gives customers more autonomy over minor scanning and transactional issues.

As we can observe from the respondent suggested recommendations, with the exception of the need to expand the checkout area and to increase the number of employees to assist customers using SSCOs, the other recommendation reflects the themes to emerge from the research regarding technical and processual issues with the technology (Dillon, 2010; Meuter et al., 2000). Respondents understood that self-service by its very definition requires to be quick and convenient; their recommendations of having more staff to expedite the transaction would assist with this, however, integrating more staff may also have the negative effect of further controlling customers and, perhaps, slowing down the process even more. Therefore, the recommendation regarding ensuring that SSCOs worked every time, although difficult, some may say improbable to achieve, is perhaps a better option to aspire to, in conjunction with investigating the use of space around the checkout area to reduce negative emotions experienced by customers, those feelings of irritation, frustration and, ultimately, dissatisfaction.

\section{CONCLUSION}

This study examined consumer perceptions and experiences with SSCOs, consolidating research in the area of consumer interaction and experiences with SSTs in general and SSCOs in particular. The study also took research forward with regards to attempting to understand the emotional relationship customers have with the technology and suggested potential solutions to reduce customer dissatisfaction and frustration. The research found that the majority of respondents were motivated to use SSCOs because of time-saving and convenience. The research also revealed, however, that some respondents acknowledged that SSCOs were not always quicker when compared to staffed checkouts, because of technical issues, lack of staff assistance and the impersonal, sometimes stressful nature of interacting with the technology in cramped conditions.

Although a minority of respondents felt positive about SSCOs as a platform to provide consumers with a choice, most respondents perceived the shopping experience negatively. The majority of respondents felt isolated, controlled and frustrated by the cumulative effect of time delays caused by technical and processual issues within a restrictive environment. This negative experience influenced the majority of respondents and their decision not to use the technology again unless certain situations occurred, i.e., situations which centred on convenience, namely a small number of items, being in a hurry, and/or long queues at staffed checkouts. The majority of respondents' opinions did not change from their initial perceptions and indicated that they would prefer not to use the technology in the future.

The findings gave rise to particular areas for future research. In the first instance, a future study may investigate customer preference for using staffed checkouts for bulky items. Although this research made the logical assumption that respondent rationale was related to the product being more difficult to scan, i.e. finding the barcode and positioning the product in front of the scanner, further research is required to understand the underlying reasons for these responses. Secondly, future research should explore the impact of staff (physical or virtual) on the user experience of SSCO technology to ascertain whether providing more verbal cues and explanation to users would prove beneficial and whether there is a need for better training of staff or the incorporation of further automation or digitisation in the process. Thirdly, future research should also further investigate respondents' emotional engagement with the technology, examining the motivation for the use and the feelings of isolation, anxiety, frustration and being controlled while using SSCOs utilising visual and physiological techniques. This future research will be able to conceptualise and empirically test customer perceptions and experiences, ultimately informing research into better customer engagement with SSCOs.

\section{LITERATURE}

Åkesson, M., Edvardsson, B., \& Tronvoll, B. (2014). Customer experience from a self-service system perspective. Journal of Service Marketing, 25(5), 677698.

Anderson, E. W., et al. (1994). Customer satisfaction, market share, and profitability: Findings from Sweden. Journal of Marketing, 58(3), 53-66.

Andreassen, T. W., \& Lindestad, B. (1998). Customer loyalty and complex services. International Journal of Service Industry Management, 9(1), 7-23. 
Anitsal, I., \& Schumann, D. W. (2007). Towards a conceptualization of customer productivity: The customer's perspective on transforming customer labor into customer outcomes using technologybased self-service options. The Journal of Marketing Theory and Practice, 15(4), 349-363.

Anon. (2016). Supermarket lose over $£ 486 \mathrm{BN}$ a year in purchases abandoned at self-scan. Business Matters. Retrieved from http://www. bmmagazine.co.uk/news/supermarkets-lose486bn-year-purchases-abandoned-self-scan/?utm_ campaign $=$ twitter\&utm_medium $=$ twitter\&utm _ source $=$ twitter

Anon. (2014). Unexpected item in the bagging area could be a thing of the past. The Telegraph. Retrieved from http://www.telegraph.co.uk/finance/newsbysector/ retailandconsumer/11142679/Unexpected-item-inthe-bagging-area-could-be-a-thing-of-the-past.html

Arnfield, R. (2014). Supermarket self-checkout technology approaching tipping point? Kioskmarketplace. Retrieved from http://www.kioskmarketplace.com/ articles/supermarket-self-checkout-technologyapproaching-tipping-point/

Ballantyne, D., Williams, J., \& Aitken, R. (2011). Introduction to service-dominant logic: from propositions to practice. Industrial Marketing Management, 40(2), 179-180.

Bandura, A. (1986). Social foundation of thought and action: A social-cognitive theory. Englewood Cliffs, United States: Prentice Hall.

Beerli, A., Martin, J. D., \& Quintana, A. (2004). A model of customer loyalty in the retail banking sector. European Journal of Marketing, 38(1/2), 253-275.

Bessière, K., Newhagen, J. E., Robinson, J. P., \& Shneiderman, B. (2006). A model for computer frustration: the role of instrumental and dispositional factors on incident, session, and post-session frustration and mood. Computers in Human Behavior, 22, 941-961.

Bloemer, J., \& De Ruyter, K. (1998). On the relationship between store image, store satisfaction and store loyalty. European Journal of Marketing, 32(5/6), 499513.

Bolger, N., Davis, A., \& Rafaeli, E. (2003). Diary methods: Capturing life as it is lived. Annual Review of Psychology, 54, 579-616.

Burke, R. R. (2002). Technology and the customer interface: What consumers want in the physical and virtual store. Journal of the Academy of Marketing Science, 30(4), 411-432.

Butcher, K., Sparks, B. A., \& O'Callaghan, F. V. (2001). Evaluative and relational influences on service loyalty. International Journal of Service Industry Management, 12(4), 310-327.

Collier, J. E., \& Kimes, S. E. (2013). Only if it is convenient: understanding how convenience influences selfservice technology evaluation. Journal of Service Research, 16(1), 39-51.

Dabholkar, P. A., Bobbitt, L. M., \& Lee, E-J. (2003). Understanding consumer motivation and behaviour related to self-scanning in retailing. International Journal of Service Industry Management, 14(1), 5995.
Dabholkar, P. A., \& Bagozzi, R. P. (2002). An attitudinal model of technology-based self-service: Moderating effects of consumer traits and situational factors. Journal of Marketing Theory and Practice, 30(3), 184201.

Dabholkar, P. A. (1996). Consumer evaluations of new technology-based self-service options: An investigation of alternative models of service quality. International Journal of Research in Marketing, 13(1), 29-51.

Davis, F. D. (1989). Perceived usefulness, perceived ease of use, and user acceptance of information technology. MIS Quarterly, 13(3), 319-340.

Davis, S., \& Wiedenbeck, S. (2001). The mediating effects of intrinsic motivation, ease of use and usefulness perceptions on performance in first-time and subsequent computer users. Interacting with Computers, 13(5), 549-580.

De Ruyter, K., \& Bloemer, J. (1999). Customer loyalty in extended service settings: The interaction between satisfaction, value attainment and positive mood. International Journal of Service Industry Management, 10(3), 320-336.

Dean, D. H. (2008). Shopper age and the use of self-service technologies. Managing Service Quality, 18(3), 225238.

Denzin, N. K., \& Lincoln, Y. S. (2011). The Sage handbook of qualitative research ( $4^{\text {th }}$ edition). Thousand Oaks, United States: Sage.

Dillon, C. (2010). The disadvantages of self service checkouts. Ehow. Retrieved from http://www.ehow. com/list_7615063_disadvantages-self-servicecheckouts.html

Ding, X., Verma, R., \& Iqbal, Z. (2007). Self-service technology and online financial service choice. International Journal of Service Industry Management, 18(3), 246-268.

Ejdys, J. (2018). Building technology trust in ICT application at a university. International Journal of Emerging Markets, 13(5), 980-997.

Ejdys, J., \& Halicka, K. (2018). Sustainable Adaptation of New Technology - The Case of Humanoids Used for the Care of Older Adults. Sustainability, 10(10), 3770.

Elo, S., \& Kyngäs, H. (2008). The qualitative content analysis process. Journal of Advanced Nursing, 62(1), 107-115.

Engel, J. F., Blackwell, R. D., \& Miniard, P. W. (1995), Consumer Behavior. $6^{\text {th }}$ ed, Chicago, United States: Dryden Press.

Fitzsimmons, J.A. (2003). Is self-service the future of services? Managing Service Quality, 13(6), 443-444.

German EHI Retail Institute (2017). EHI-Studie zu SelfCheckout und Self-Scanning im deutschen Handel. EHI Retail Institute. Retrieved from https://www.ehi. org/de/pressemitteilungen/selbst-ist-der-kunde/

Grossman, R. P. (1998). Developing and managing effective customer relationships. Journal of Product \& Brand Management, 7(1), 27-40.

Heskett, J., Sasser, Jr, W. E., \& Schlesinger, L. (1997). The service profit chain: How leading companies link profit and growth to loyalty, satisfaction and value, New York, United States: The Free Press. 
Hilton, T., Hughes, T., Little, E., \& Marandi, E. (2013). Adopting self-service technology to do more with less. Journal of Services Marketing, 27(1), 3-12.

Hoffman, D. L., Novak, T. P., \& Schlosser, A. E. (2003). Locus of control, web use, and consumer attitudes. Journal of Public Policy \& Marketing, 22(1), 41-57.

Hogarth, J. M., Hilgert, M. A., \& Kolodinsky, J. M. (2004). Customers' resolution of credit card problems and exit behaviours. Journal of Services Marketing, 18(1), 19-34.

Jamal, A. (2004). Retail banking and customer behaviour: A study of self-concept, satisfaction and technology usage. International Review of Retail, Distribution and Consumer Research, 14(3), 357-379.

Jammi, N. (2014). Why impatient customers really love self- service. Kayako. Retrieved from https://www. kayako.com/blog/why-impatient-customers-reallylove-self-service/

Javalgi, R., \& Moberg, C. (1997). Service loyalty: Implications for service providers. Journal of Services Marketing, 11(3), 165-179.

Jayasimha, K. R., \& Nargundkar, R. (2006). Adoption of self service bill payment technologies (SSBPTS): A conceptual model. Journal of Services Research, 6(2), 119-134.

Jones, D. (2016). Shop till you stop. The Sun, July 16th, 18.

Jones, D. (2015). No more nagging with the bagging. The Sun, July 30th, 3.

Kleemann, F., Voß, G. G., \& Rieder, K. (2008). Un(der)paid innovators: the commercial utilization of consumer work through Crowdsourcing. Science, Technology and Innovation Studies, 4(1), 5-26.

Knapton, S. (2016). Self-service checkouts turn honest shoppers into thieves, warn criminologists. The Telegraph. Retrieved from http://www.telegraph. co.uk/science/2016/08/02/self-service-checkoutsturn-honest-shoppers-into-thieves-warn-cr/

Laurenceau, J. P., \& Bolger, N. (2005). Using diary methods to study marital and family processes. Journal of Family Psychology, 19(1), 86-97.

Lazar, J., Jones, A., Hackley, M., \& Shneiderman, B. (2006). Severity and impact of computer user frustration: A comparison of student and workplace users. Interacting with Computers, 18(2), 187-207.

Lee, H. J., \& Lyu, J. (2016). Personal values as determinants of intentions to use self-service technology in retailing. Computers in Human Behaviour, 60, 322332.

Lee, H. J., Cho, H. J., Xu, W., \& Fairhurst, A. (2010). The influence of consumer traits and demographics on intention to use retail self-service checkouts. Marketing Intelligence \& Planning, 28(1), 46-58.

Liu, L. W., Yang, W. G., \& Liu, W. H. (2017). Building the B2B customer loyalty: A role of relationship quality. Polish Journal of Management Studies, 16(1), 105114.

Locke, E. A., \& Latham, G. P. (1990). A theory of goal setting and task performance. Englewood Cliffs, United States: Prentice Hall.

McNamara, N., \& Kirakowski, J. (2008). Measuring the human element in complex technologies.
International Journal of Technology and Human Interaction, 4(1), 1-14.

Merrilees, B., \& Miller, D. (2001). Superstore interactivity: a new self-service paradigm of retail service. International Journal of Retail and Distribution Management, 29(8), 379-389.

Meuter, M. L., Ostrom, A. L., Roundtree, R. I., \& Bitner, M. J. (2000). Self-service technologies: understanding customer satisfaction with technology-based service encounters. Journal of Marketing, 64, 50-64.

Miranda, M. J., Konya, L., \& Havrila, I. (2005). Shoppers' satisfaction levels are not the only key to store loyalty. Marketing Intelligence \& Planning, 23(2), 220-232.

Mittal, B., \& Lassar, W. M. (1998). Why do customers switch? The dynamics of satisfaction versus loyalty. The Journal of Services Marketing, 12(3), 177-194.

Muller, A. (2008). Self-service shopping: Advantages for both retailers and customers. The Retail Digest, December, 50-53.

Nysveen, H., Pederson, P. E., \& Thorbjornsen, H. (2005). Intentions to use mobile services: Antecedents and cross-service comparisons. Journal of the Academy of Marketing Science, 33(2), 330-347.

Oliver, R. L. (1999). Whence customer loyalty? Journal of Marketing, 63(5), 33-44.

Oliver, R. L. (1997). Satisfaction: A behavioural perspective on the customer. New York, United States: McGrawHill.

Oliver, R. L. (1993). Cognitive, affective and attribute bases of the satisfaction response. Journal of Consumer Research, 20(3), 418-430.

Oyedele, A., \& Simpson, P. M. (2007). An empirical investigation of consumer control factors on intention to use selected self-service technologies. International Journal of Service Industry Management, 18(3), 287-306.

Pirzada, K. (2016). Providers and users' perception of voluntary need of human resource disclosure: A content analysis. Polish Journal of Management Studies, 14(2), 232-242.

Reinders, M. J., Dabholkar, P. A., \& Frambach, R. T. (2008). Consequences of forcing consumers to use technology-based self-service. Journal of Service Research, 11(2), 107-123.

Retail Technology. (2010). Carrefour extends self-scanning roll out. Retail Technology. Retrieved from http:// www.retailtechnology.co.uk/news/1543/carrefourextends-self-scanning-roll-out/

Simon, F., \& Usunier, J. (2007). Cognitive, demographic, and situational determinants of service customer preference for personnel-in-contact over self-service technology. International Journal of Research in Marketing, 24, 163-173.

Strauss, A., \& Corbin, J. (2008). Basics of Qualitative Research (3rd edition). Thousand Oaks, United States: Sage.

Steenkamp, J. B. E. M., \& Maydeu-Olivares, A. (2015). Stability and change in consumer traits: Evidence from a 12-year longitudinal study, 2002-2013. Journal of Marketing Research, 52(3), 287-308. 
Swan, J. E., Bowers, M. R., \& Richardson, L. D. (1999). Customer trust in a salesperson: An integrative review and meta-analysis of the empirical literature. Journal of Business Research, 44(2), 93-107.

Turner, J. J., \& Borch, K. (2012). Store and satisfaction: An analysis of customer perceptions of self-scan checkouts. Journal of Marketing at Retail, 1(2), 6-16.

Urbany, J. E. Dickson, P. R., \& Sawyer, A. G. (2000). Insights into cross- and within-store price search: retailer estimates vs. consumer self-reports. Journal of Retailing, 76(2), 243-258.

Uusitalo, O. (2001). Consumer perceptions of grocery retail formats and brands. International Journal of Retail and Distribution Management, 29(5), 214-225.

Venetis, K. A., \& Ghauri, P. N. (2000). The importance of service quality on customer retention: An empirical study of business service relationships. Proceedings of the Marketing in a Global Economy Conference, Buenos Aires, June $28^{\text {th }}$-July $1^{\text {st }}, 215-224$.

Venkatesh, V., Thong, J. Y. L., \& Xu, X. (2016). Unified theory of acceptance and use of technology: A synthesis and the road ahead. Journal of the Association for Information Systems, 17(5), 328-376.

Venkatesh, V. (2000). Determinants of perceived ease of use: Integrating control, intrinsic motivation and emotion into the technology acceptance model. Information Systems Research, 11(2), 342-365.

Voss, G. G., \& Rieder, K. (2005). The working customer: when consumers become unpaid employees. New York, united States: Campus.

Vouk, R., Guszak, I., \& Sisek, B. (2011). The role of selfservice technologies in Croatian grocery retailing. Annals of DAAAM for 2011 \& Proceedings of the $22^{\text {nd }}$ International DAAAM Symposium, 22(1), 1063-1064.

Wang, C., Harris, J., \& Patterson, P. (2013). The roles of habit, self-efficacy, and satisfaction in deriving continued use of self-service technologies: A longitudinal study. Journal of Service Research, 16(3), 400-414.

Wong, A. (2004). The role of emotional satisfaction in service encounters. Managing Service Quality, 14(5), 365-376.

Wynne, E. (2016). Self-service checkouts normalise, excuse supermarket stealing, research shows. ABC News. Retrieved from http://www.abc.net.au/news/201607-21/self-service-checkouts-normalising-theft-forcustomers-research/7648910

Yang, Y-C., Liu, S-W., \& Ding. M-C. (2012). Determinants of self-service technology adoption. African Journal of Business Management, 6(40), 10514-10523.

Yavas, U., \& Babakus, E. (2009). Retail store loyalty: A comparison of two customer segments. International Journal of Retail \& Distribution Management, 37(6), 477-492. 